\title{
Mechanism-Based Inhibition of Myeloperoxidase by Hydrogen Peroxide: Enhancement of Inactivation Rate by Organic Donor Substrates
}

\author{
Femi J. Olorunniji ${ }^{1,4, *}$, Martin O. Iniaghe ${ }^{2}$, Joseph O. Adebayo ${ }^{1}$, Sylvia O. Malomo ${ }^{1}$ and \\ Suara A. Adediran ${ }^{3,5, *}$ \\ ${ }^{I}$ Department of Biochemistry, Faculty of Science, University of Ilorin, Ilorin, Nigeria \\ ${ }^{2}$ Department of Biochemistry, Faculty of Science, Ambrose Alli University, Ekpoma, Nigeria \\ ${ }^{3}$ Department of Chemistry, Faculty of Science, University of Ilorin, Ilorin, Nigeria \\ ${ }^{4}$ Division of Molecular and Cellular Biology, Faculty of Biomedical and Life Sciences, University of Glasgow, Glasgow \\ G12 $8 Q Q$, U.K \\ ${ }^{5}$ Department of Chemistry, Wesleyan University, Middletown, CT 06459, USA
}

\begin{abstract}
The effects of two hydrazine derivatives (isoniazid and hydralazine) on the inactivation of myeloperoxidase by $\mathrm{H}_{2} \mathrm{O}_{2}$ were investigated. Incubation of $20 \mathrm{nM}$ myeloperoxidase with $0.25 \mathrm{mM} \mathrm{H}_{2} \mathrm{O}_{2}$ alone caused a time-dependent irreversible loss of tetramethylbenzidine oxidation activity with a pseudo-first order inactivation rate constant of 0.057 $\min ^{-1}$. The hydrazine derivatives increased the inactivation rate in a concentration-dependent manner. Inactivation of the enzyme by $\mathrm{H}_{2} \mathrm{O}_{2}$ with or without the hydrazides showed a saturation kinetics pattern. Steady state kinetics analysis suggests that the hydrazides likely inactivate myeloperoxidase using a similar inactivating species as does $\mathrm{H}_{2} \mathrm{O}_{2}$. A bimolecular rate constant, specific inactivation rate enhancement factor $\left(\mathrm{k}^{*}{ }_{\mathrm{enh}}\right)$ is proposed as a formal description of the inactivation rate stimulation by the hydrazides. This parameter potentially avoids confounding the finite inactivation due to $\mathrm{H}_{2} \mathrm{O}_{2}$ with that caused by the presence of the hydrazides. The relevance of these findings and the constants derived to the analysis of suicide inactivation of peroxidases by reductant substrates are discussed.
\end{abstract}

Keywords: Myeloperoxidase, Isoniazid, Hydralazine, Mechanism-based inhibition, Inactivation kinetics.

\section{INTRODUCTION}

The peroxidases (donor: $\mathrm{H}_{2} \mathrm{O}_{2}$ oxidoreductase) are haem proteins, which mediate the one-electron oxidation of a wide array of organic compounds (phenols, anilines, $\beta$-diketones etc) with the concomitant reduction of $\mathrm{H}_{2} \mathrm{O}_{2}$ to $\mathrm{H}_{2} \mathrm{O}$ [1]. The catalytic cycles of most peroxidases resemble that described for horseradish peroxidase (HRP) [1]. In this scheme, the ferric peroxidase ( $\mathrm{Fe}^{\mathrm{III}}-\mathrm{Px}$ ) donates two electrons to $\mathrm{H}_{2} \mathrm{O}_{2}$ resulting in cleavage of $\mathrm{H}_{2} \mathrm{O}_{2}$ and formation of a redox intermediate of the enzyme called compound I (CI). CI consists of an oxoferryl protein cation radical, in which one of the oxidation equivalents exists as the ferryl ion, Fe (IV) and the other as a porphyrin-centred cation radical. CI reacts with reductants $(\mathrm{RH})$ to generate substrate free radicals and compound II (CII), another redox intermediate in which the oxoferryl species remains intact but the cation radical is reduced. A one-electron reduction of CII by a second RH molecule regenerates the ferric enzyme and forms a second equivalent of $\mathrm{R}$.

\footnotetext{
*Address correspondence to these authors at the Division of Molecular \& Cellular Biology, Faculty of Biomedical \& Life Sciences, University of Glasgow, Glasgow G12 8QQ, United Kingdom; Tel: +441413303331;

E-mail: f.olorunniji@bio.gla.ac.uk and Department of Chemistry, Wesleyan University, Middletown, Connecticut 06459, USA;

E-mail: sadediran@wesleyan.edu
}

$$
\begin{aligned}
& \mathrm{Fe}^{\mathrm{III}}-\mathrm{Px}+\mathrm{H}_{2} \mathrm{O}_{2} \longrightarrow \mathrm{CI}+\mathrm{H}_{2} \mathrm{O} \\
& \mathrm{CI}+\mathrm{RH} \longrightarrow \mathrm{CII}+\mathrm{R} \\
& \mathrm{CII}+\mathrm{RH} \longrightarrow \mathrm{Fe}^{\mathrm{III}}-\mathrm{Px}+\mathrm{R}+\mathrm{H}_{2} \mathrm{O}
\end{aligned}
$$

Another redox intermediate, Compound III (CIII) is formed in the course of peroxidase catalytic cycle. It is catalytically inactive and exists as a resonance form between the $\mathrm{Fe}^{\mathrm{II}}-\mathrm{O}_{2}$ and $\mathrm{Fe}^{\mathrm{III}}-\mathrm{O}_{2}^{-}$complexes.

Myeloperoxidase (MPO) is a heterodimeric, cationic and glycosylated haem enzyme. The enzyme is a $140-\mathrm{kDa}$ dimer of identical halves, each consisting of two polypeptide chains of 108 and 466 amino acids. Each half contains a covalently attached haem [2]. X-ray crystallographic studies show that $\mathrm{H} 95$ and R239 are likely involved in the catalytic mechanism of MPO [3]. Like the other haem peroxidases, MPO combines with hydrogen peroxide to form the highly reactive redox intermediate called compound I. The high redox potential of this intermediate confers MPO with the unusual ability to oxidize chloride ion to hypochlorous acid with the concomitant regeneration of native enzyme [4].

MPO differs significantly from other peroxidases in its chemical and spectroscopic properties. For instance, its Soret band is red-shifted in the optical absorption and in its pyridine haemochrome spectrum. While there are spectral and kinetics differences between MPO and other mammalian 
peroxidases, the active site amino acid sequence of the enzymes share a high degree of homology. Virtually all known peroxidases are inactivated by $\mathrm{H}_{2} \mathrm{O}_{2}$ and other hydroperoxides at relatively high concentrations [1]. This substrate inactivation leads to the modification of the haem prosthetic group and formation of a verdohaemoprotein as the final product. The mechanism of the inactivation by hydrogen peroxide is yet to be completely resolved. There appears, however, to be a consensus that compound III formation is crucial to the process [5]. The existence of compound III as the peroxy iron (III) porphyrin free radical resonant form can facilitate the transfer of electrons from the ferrous state to an extra hydrogen peroxide molecule thereby generating hydroxyl radical. This highly reactive species has the propensity to attack the haem porphyrin ring and lead to irreversible inactivation [6].

Some reports suggest that inactivation of MPO by $\mathrm{H}_{2} \mathrm{O}_{2}$ is not an effective process and that the presence of a radical generating reducing substrate is needed for appreciable inactivation to occur [7-9]. Inactivation of peroxidases by certain reductants is a feature of peroxidase catalysis. Such substrates are oxidized in the presence of $\mathrm{H}_{2} \mathrm{O}_{2}$, a process that is concomitant with enzyme inactivation. In this study, we have used a steady state kinetics approach to demonstrate that MPO is irreversibly inactivated by excess $\mathrm{H}_{2} \mathrm{O}_{2}$ in the absence of reducing substrate. The rate of the inactivation process is enhanced in the presence of suicide substrates, isoniazid (ISD) and hydralazine (HDL), which are known inactivators of the enzyme [10,11]. We also describe a novel bimolecular rate constant that formally describes the activating effect of a suicide donor substrate on hydroperoxideinitiated inactivation of peroxidases.

\section{MATERIALS AND METHODS}

\section{Reagents, Substrates and Enzyme}

ISD, HDL, $\mathrm{H}_{2} \mathrm{O}_{2}$ and horseradish peroxidase were products of Sigma-Aldrich Company (Dorset, Poole, UK). Other chemicals and reagents used were of high quality research grade. MPO was isolated and purified from human polymorphonuclear neutrophils by means of a combination of published procedures with slight modifications $[2,12]$. The enzyme preparation had a purity index $\left(\mathrm{A}_{428} / \mathrm{A}_{280}\right)$ of 0.70 . The concentration of MPO, expressed as haem concentration was measured spectrophotometrically based on Soret absorbance at $428 \mathrm{~nm}$ by using a millimolar absorption coefficient per haem of $89 \mathrm{mM}^{-1} \mathrm{~cm}^{-1}$ [13].

\section{Determination of Enzyme Activity}

MPO activity was determined by measuring the rate of oxidation of tetramethylbenzidine (TMB) at $20{ }^{\circ} \mathrm{C}$ in a 3.0 $\mathrm{ml}$ reaction mixture containing $80 \mathrm{mM}$ sodium acetate buffer, $\mathrm{pH} 5.4,1.6 \mathrm{mM}$ TMB and $0.3 \mathrm{mM} \mathrm{H}_{2} \mathrm{O}_{2}$. The initial rate of formation of the bluish charge transfer complex was measured at $655 \mathrm{~nm}$ [14]. Reactions were initiated by adding $\mathrm{H}_{2} \mathrm{O}_{2}$ as the last component of the mixture. Initial rate of TMB oxidation was determined from the linear portion of the time course for the appearance of the charge transfer complex at $655 \mathrm{~nm}$ [15]. Desired concentrations of $\mathrm{H}_{2} \mathrm{O}_{2}$ were prepared daily from a $30 \%$ stock solution and determined spectrophotometrically using horseradish peroxidase as catalyst for $\mathrm{I}_{3}^{-}$generation from $\mathrm{I}^{-}$[16]. Concentrations determined this way were confirmed by absorbance measurements at $240 \mathrm{~nm}$, taking $E_{240}$ as $43.6 \mathrm{M}^{-1} \mathrm{~cm}^{-1}$ [17]. Kinetics absorbance measurements were performed with a UV/visible spectrophotometer model Camspec M105.

\section{Inactivation Kinetics}

The kinetics of irreversible inactivation of MPO by $\mathrm{H}_{2} \mathrm{O}_{2}$ and the hydrazides were studied under pseudo-first order conditions. MPO $(20 \mathrm{nM})$ was incubated with the hydrazides $(0.25-1.50 \mathrm{mM})$ at $20{ }^{\circ} \mathrm{C}$ in $100 \mathrm{mM}$ phosphate buffer $(\mathrm{pH}$ 7.4) in the presence of $\mathrm{H}_{2} \mathrm{O}_{2}(0.25 \mathrm{mM})$ in a total reaction volume of $1.0 \mathrm{ml}$. Incubation of MPO with $\mathrm{H}_{2} \mathrm{O}_{2}(0.25 \mathrm{mM})$ without the hydrazides was carried out under similar conditions. In all cases, $\mathrm{H}_{2} \mathrm{O}_{2}$ was added last to the incubation mixture containing MPO and hydrazide to initiate the inactivation reaction. At 3 minute intervals, aliquots of $50 \mu 1$ were withdrawn and diluted 500-fold, and the residual activities (A) were determined. This treatment would prevent the interpretation of 'reversibly inactivated' enzyme in the form of compound III as completely inactivated enzyme [18]. The activity of an equal amount of the enzyme without preincubating with $\mathrm{H}_{2} \mathrm{O}_{2}$ and the hydrazides was determined and taken as the control $\left(\mathrm{A}_{\mathrm{o}}\right)$. Plots of $\ln \left(\mathrm{A} / \mathrm{A}_{\mathrm{o}}\right)$ against time were used to obtain the pseudo first order inactivation rate constants $\left(\mathrm{k}_{\mathrm{obs}}\right)$. The concentration dependence of $\mathrm{H}_{2} \mathrm{O}_{2}$ on inactivation rate in the presence and absence of both hydrazides was studied over a $\mathrm{H}_{2} \mathrm{O}_{2}$ concentration range of 0.1-1.25 mM. MPO $(20 \mathrm{nM})$ was incubated with the appropriate $\mathrm{H}_{2} \mathrm{O}_{2}$ concentration in $100 \mathrm{mM}$ phosphate buffer, $\mathrm{pH} 7.4$ at $20{ }^{\circ} \mathrm{C}$ in a $1.0 \mathrm{ml}$ reaction volume. First order inactivation rates $\left(k_{o b s}\right)$ were determined as described above and the experiments were carried out with and without $0.5 \mathrm{mM}$ ISD or HDL. The $\mathrm{H}_{2} \mathrm{O}_{2}$ and hydrazide concentrations used in this study were at least ten times that of the enzyme. This was to ensure that pseudo-first order conditions were in operation in the inactivation processes. At least four $\mathrm{k}_{\mathrm{obs}}$ determinations were made for each $\mathrm{H}_{2} \mathrm{O}_{2}$ and hydrazide concentrations. Results of variation of $\mathrm{k}_{\text {obs }}$ with $\mathrm{H}_{2} \mathrm{O}_{2}$ concentration with or without the hydrazides were fitted to a rectangular hyperbola using non-linear regression generated by a computer programme, Enzfitter (Biosoft Corp.). Double reciprocal transformation of the data was carried out using the same software to obtain Kitz-Wilson inactivation constants, $\mathrm{k}_{\text {inact }}$ and $\mathrm{K}_{\mathrm{i}}$ according to the following equation

$1 / /_{\text {kobs }}=\mathrm{K}_{\mathrm{i}} / \mathrm{k}_{\text {inact }}\left(1 /\left[\mathrm{H}_{2} \mathrm{O}_{2}\right]\right)+1 / \mathrm{k}_{\text {inact }}$.

Two second order rate constants that describe the effect of the hydrazides on the inactivation by $\mathrm{H}_{2} \mathrm{O}_{2}$ were proposed in this study. Inactivation rate enhancement factor $\left(\mathrm{k}_{\mathrm{enh}}\right)$ and specific inactivation rate enhancement factor $\left(\mathrm{k}^{*}{ }_{\mathrm{enh}}\right)$ were calculated from the slopes of the plots of $\mathrm{k}_{\mathrm{obs}}$ and $\mathrm{k}_{\mathrm{hyd}}-\mathrm{k}_{\mathrm{per}}$ versus hydrazide concentrations respectively.

\section{RESULTS}

We investigated the inactivation of $\mathrm{H}_{2} \mathrm{O}_{2}$ by MPO in the absence of a reductant substrate by incubating $20 \mathrm{nM}$ of the 


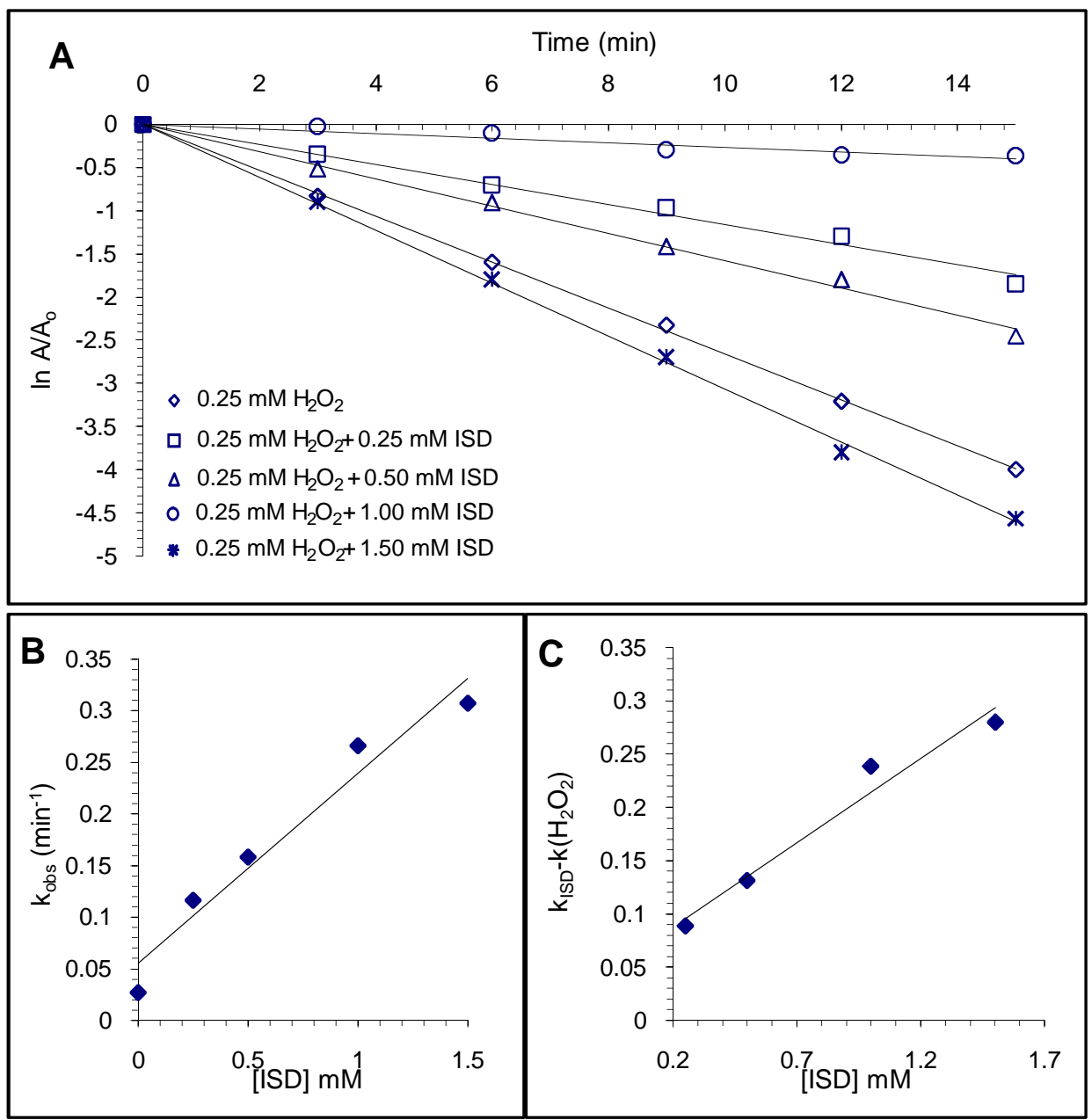

Fig. (1). Rate enhancement of $\mathrm{H}_{2} \mathrm{O}_{2}$-dependent inactivation of MPO by ISD. Panel A shows the time course of MPO inactivation by 0.25 $\mathrm{mM} \mathrm{H}_{2} \mathrm{O}_{2}$ alone and in combination with $0.25-1.50 \mathrm{mM}$ ISD. The lines are plots of $\ln \mathrm{A}_{\mathrm{A}} \mathrm{A}_{\mathrm{o}}$ versus time where $\mathrm{A}_{\mathrm{o}}$ and $\mathrm{A}$ are activities at time zero and at the corresponding times indicated on the plots respectively. The slopes of the lines represent the first order inactivation rates $\left(\mathrm{k}_{\mathrm{obs}}\right)$ and were plotted versus ISD concentration in Panel $\mathbf{B}$ to obtain the inactivation rate enhancement factor $\left(\mathrm{k}_{\mathrm{enh}}\right)$. Panel $\mathbf{C}$ shows the determination of the bimolecular inactivation rate enhancement constant $\left(\mathrm{k}^{*}{ }_{\text {enh }}\right)$ by plotting $\mathrm{k}_{\text {hyd }}-\mathrm{k}_{\text {per }}$ versus ISD concentration. Reaction conditions are as follows. MPO $(20 \mathrm{nM})$ was incubated with the hydrazides $(0.25-1.50 \mathrm{mM})$ at $20{ }^{\circ} \mathrm{C}$ in $100 \mathrm{mM}$ phosphate buffer $(\mathrm{pH} 7.4)$ in the presence of $\mathrm{H}_{2} \mathrm{O}_{2}(0.25 \mathrm{mM})$ in a total reaction volume of $1.0 \mathrm{ml}$. A similar incubation was carried out with $\mathrm{H}_{2} \mathrm{O}_{2}(0.25 \mathrm{mM})$ without the hydrazides under similar conditions. In all cases, $\mathrm{H}_{2} \mathrm{O}_{2}$ was added last to initiate the inactivation reaction. At 3-minute intervals, aliquots of $50 \mu \mathrm{l}$ were withdrawn and diluted 500-fold before determining the residual activities (A). Activity of an equal amount of the enzyme without pre-incubating with $\mathrm{H}_{2} \mathrm{O}_{2}$ and the hydrazides was determined and taken as the control $\left(\mathrm{A}_{\mathrm{o}}\right)$. Plots of ln $\left(\mathrm{A} / \mathrm{A}_{\mathrm{o}}\right)$ against time were used to obtain the pseudo first order inactivation rate constants $\left(\mathrm{k}_{\mathrm{obs}}\right)$.

enzyme with $0.25 \mathrm{mM}$ hydrogen peroxide and the residual activity was determined at regular intervals. Fig. (1A) shows that $0.25 \mathrm{mM} \mathrm{H}_{2} \mathrm{O}_{2}$ caused a time-dependent irreversible loss of MPO activity. A pseudo-first order rate constant of 0.116 $\mathrm{min}^{-1}$ was calculated from the plot for the inactivation of MPO by $\mathrm{H}_{2} \mathrm{O}_{2}$ alone. Inclusion of ISD $(0.25-1.50 \mathrm{mM})$ in the incubation mixture led to increase in the inactivation rate. The inactivation process retained a pseudo-first order kinetics pattern in the presence of ISD. The inctivation rate enhancement by ISD was concentration dependent as shown in Fig. (1B). The time and concentration dependence of ISD effect on MPO inactivation suggests that the process is mechanism-based and describable in definite kinetics terms. Fig. (2) shows the effect of HDL on MPO inactivation by $\mathrm{H}_{2} \mathrm{O}_{2}$ as described above for ISD. There is a linear relationship between inactivation enhancement rates and HDL concentration as was observed for ISD. However, HDL is less effective than ISD.

The hydrazides showed concentration-dependent effects on the inactivation of MPO by $\mathrm{H}_{2} \mathrm{O}_{2}$. Fig. (1B) is a plot of the first order rate inactivation constant against ISD 

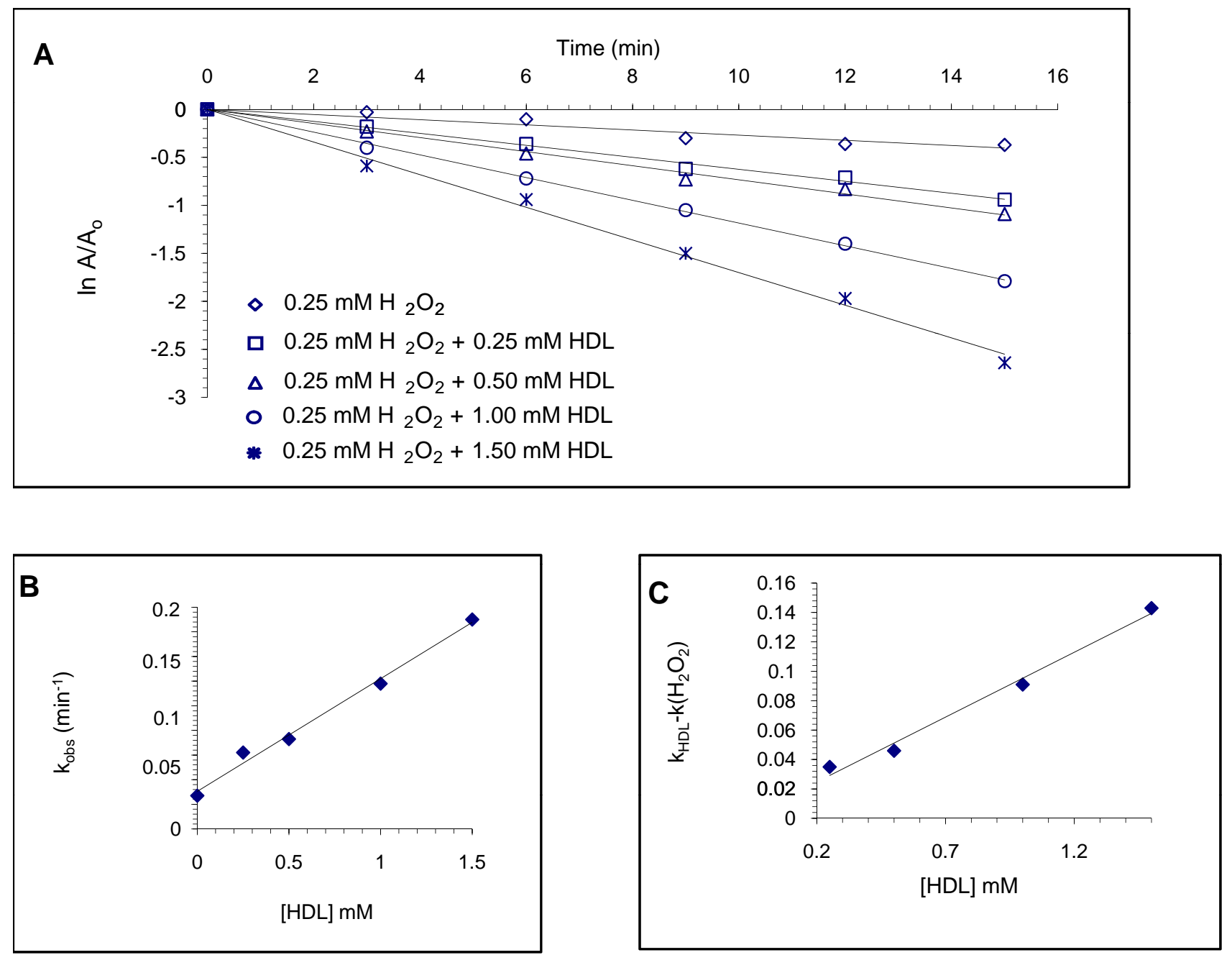

Fig. (2). Rate enhancement of $\mathrm{H}_{2} \mathrm{O}_{2}$-dependent inactivation of MPO by HDL. Panel A shows the time course of MPO inactivation by $0.25 \mathrm{mM} \mathrm{H}_{2} \mathrm{O}_{2}$ alone and in combination with 0.25-1.50 mM HDL. The lines are plots of $\ln \mathrm{A} / \mathrm{A}_{\mathrm{o}}$ versus time where $\mathrm{A}_{\mathrm{o}}$ and $\mathrm{A}$ are activities at time zero and at the corresponding time indicated on the plots respectively. The slopes of the lines represent the first order inactivation rates $\left(\mathrm{k}_{\mathrm{obs}}\right)$ and were plotted versus HDL concentration in Panel $\mathbf{B}$ to obtain the inactivation rate enhancement factor $\left(\mathrm{k}_{\mathrm{enh}}\right)$. Panel $\mathbf{C}$ shows the determination of the bimolecular inactivation rate enhancement constant $\left(\mathrm{k}^{*}{ }_{\text {enh }}\right)$ by plotting $\mathrm{k}_{\mathrm{hyd}}-\mathrm{k}_{\mathrm{per}}$ versus HDL concentration. Reaction conditions are as described in Fig. (1).

concentration. There is a linear correlation between $\mathrm{k}_{\mathrm{obs}}$ and ISD concentration. From the slope of this plot, a bimolecular inactivation rate enhancement factor $\left(\mathrm{k}_{\mathrm{enh}}\right)$ of $0.184 \mathrm{~min}^{-1}$ $\mathrm{mM}^{-1}$ was calculated. Fig. (2B) shows a similar plot for the rate enhancement due to HDL with a $\mathrm{k}_{\text {enh }}$ value of $0.091 \mathrm{~min}^{-1}$ $\mathrm{mM}^{-1}$. This parameter describes in a quantitative manner the effect of the modifiers on the inactivation occasioned by $\mathrm{H}_{2} \mathrm{O}_{2}$. This linear fit may suggest that the effect of hydrazide on $\mathrm{H}_{2} \mathrm{O}_{2}$ induced inactivation is a simple chemical event.

In order to separate the inactivation due to $\mathrm{H}_{2} \mathrm{O}_{2}$ alone from that caused by $\mathrm{H}_{2} \mathrm{O}_{2}$ in the presence of the hydrazides, another parameter $\mathrm{k}^{*}$ enh was expressed. This parameter described here as specific bimolecular inactivation rate enhancement factor, was obtained from the slope of the plot of $\mathrm{k}_{\mathrm{hyd}}-\mathrm{k}_{\mathrm{per}}$ against the concentrations of the hydrazide, [hyd]. $\mathrm{k}_{\text {enh }}=\left(\mathrm{k}_{\mathrm{hyd}}-\mathrm{k}_{\mathrm{per}}\right) /[\mathrm{hyd}]$

where $k_{\text {hyd }}$ and $k_{\text {per }}$ are the first order inactivation rate constants in the presence and absence of hydrazide respectively.

The specific inactivation enhancement rates $k^{*} e n h$ calculated from the slopes of Figs. (1C and 2C) were $0.159 \mathrm{~min}^{-1}$ $\mathrm{mM}^{-1}$ and $0.088 \mathrm{~min}^{-1} \mathrm{mM}^{-1}$ for ISD and HDL respectively. Going by these calculations, ISD was about 1.7 times more effective than HDL in enhancing the inactivation of MPO by $\mathrm{H}_{2} \mathrm{O}_{2}$. The validity of $\mathrm{k}^{*}{ }_{\text {enh }}$ is based on an assumption that the effects of hydrogen peroxide and ISD are mechanistically similar enough to be described by the same microscopic rate constants and that the different effects are additive in nature. Though the validity of this primary assumption is yet to be established, Figs. (1C and 2C) show that there is a linear correlation between $\mathrm{k}^{*}$ enh and ISD or HDL concentration. 

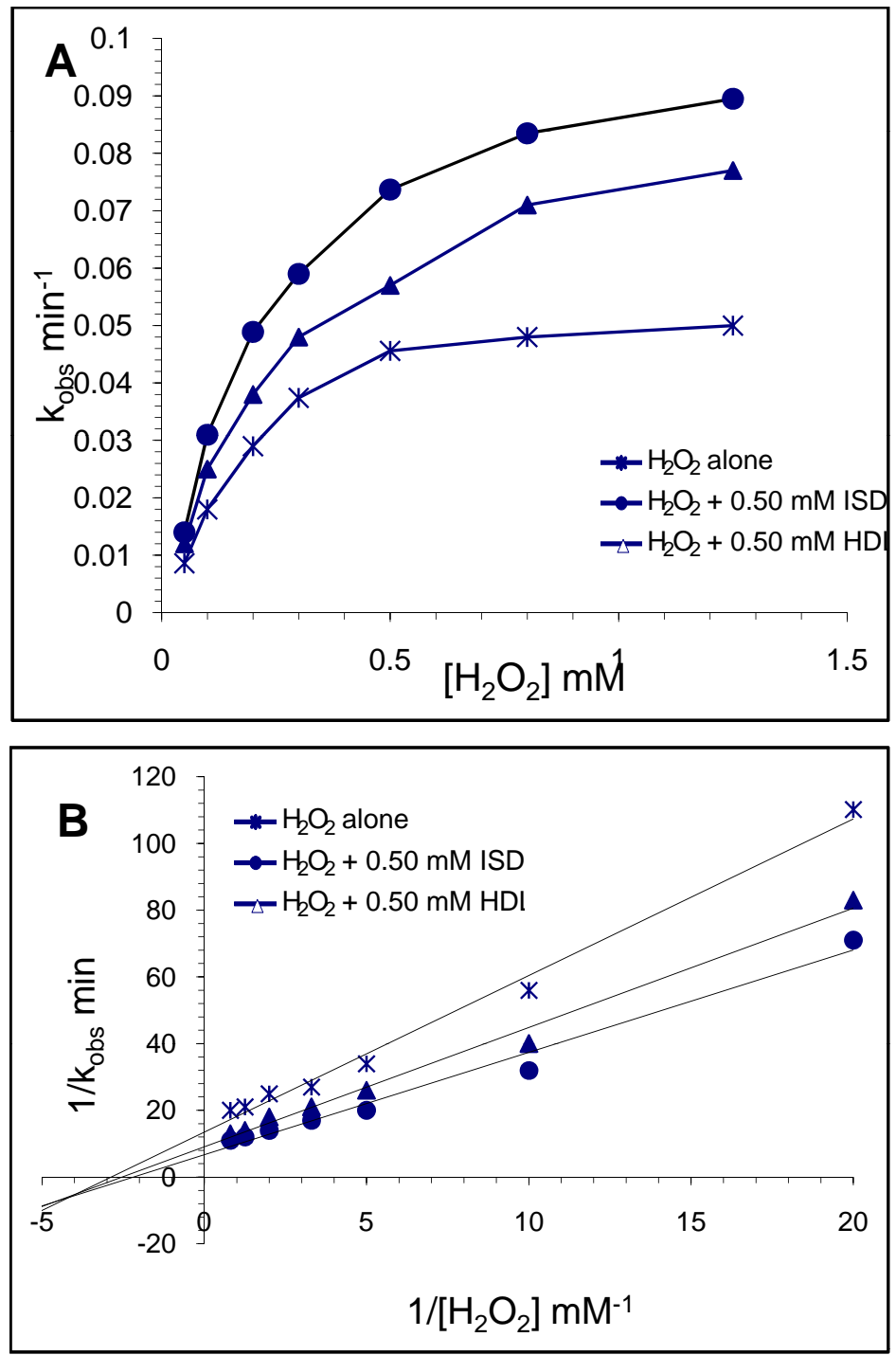

Fig. (3). Concentration dependence of $\mathrm{H}_{2} \mathrm{O}_{2}$ on MPO inactivation rate in the presence and absence of ISD and HDL. Panel A: First order inactivation rates $\left(\mathrm{k}_{\mathrm{obs}}\right)$ were plotted versus the concentration of $\mathrm{H}_{2} \mathrm{O}_{2}$. The series represents the pattern in the absence and presence of $0.5 \mathrm{mM}$ ISD and HDL. Each point represents the mean of three independent determinations. Panel B: Kitz-Wilson plots for inactivation of MPO by $\mathrm{H}_{2} \mathrm{O}_{2}$ with and without $0.5 \mathrm{mM}$ hydrazide. The data in panel A were transformed and plotted as double reciprocals for the determination of $\mathrm{k}_{\text {inact }}$ and $\mathrm{K}_{\mathrm{I}}$ and the effect of hydrazides on those constants. MPO (20 nM) was incubated with the appropriate $\mathrm{H}_{2} \mathrm{O}_{2}$ concentration in $100 \mathrm{mM}$ phosphate buffer, $\mathrm{pH} 7.4$ at $20^{\circ} \mathrm{C}$ in a $1.0 \mathrm{ml}$ reaction volume. First order inactivation rates $\left(\mathrm{k}_{\mathrm{obs}}\right)$ were determined as described in Fig (1) above and the experiments were carried out in the absence and presence of $0.5 \mathrm{mM}$ hydrazides.

Consequent upon results presented in Figs. (1 and 2) that $\mathrm{H}_{2} \mathrm{O}_{2}$ alone could cause irreversible inactivation of MPO independent of the radical-generating substrates, the kinetics of $\mathrm{H}_{2} \mathrm{O}_{2}$-dependent inactivation of MPO was investigated in the presence of the two hydrazides, ISD and HDL. Fig. (3A) shows the effects of $\mathrm{H}_{2} \mathrm{O}_{2}$ concentration on the pseudo first order inactivation rates in the presence and absence of ISD and HDL respectively. The dependence of inactivation rate constants on $\mathrm{H}_{2} \mathrm{O}_{2}$ concentration with or without the hydrazides showed a hyperbolic trend. This pattern of inactivation rate enhancement can be compared to that obtained with an activator stimulating an enzyme-catalyzed reaction [19]. It is conceivable that the mechanism of rate enhancement could be described in precise kinetics terms with defined 'activation constants' (Olorunniji et al., manuscript in preparation).
In order to obtain kinetic parameters $\mathrm{K}_{\mathrm{i}}$ and $\mathrm{k}_{\text {inact }}$ for the inactivation of MPO by $\mathrm{H}_{2} \mathrm{O}_{2}$ and the effects of the hydrazides on those constants, data from Fig. (3A) were plotted as double reciprocals and shown in Fig. (3B). The resulting straight lines are similar to those obtained from the effect of an activator on an enzyme [19].

Rate enhancement by ISD and HDL involved increasing the maximum inactivation rate constant $\left(\mathrm{k}_{\text {inact }}\right)$ due to $\mathrm{H}_{2} \mathrm{O}_{2}$ from $0.074 \mathrm{~min}^{-1}$ to 0.149 and $0.110 \mathrm{~min}^{-1}$ respectively (Table 1). On the affinity of the enzyme for hydrogen peroxide as an inactivating (suicide) substrate, the inactivator dissociation constant, $\mathrm{K}_{\mathrm{i}}$ was increased from $0.347 \mathrm{mM}$ to 0.457 and $0.393 \mathrm{mM}$ by ISD and HDL respectively. These results indicate that the hydrazides actually decreased the 
Table 1. Rate Constants for $\mathrm{H}_{2} \mathrm{O}_{2}$-Dependent Inactivation of MPO in the Absence and Presence of ISD and HDL. Values are Mean \pm Standard Deviation from Four Experiments

\begin{tabular}{|c|c|c|c|}
\hline & $\mathrm{H}_{2} \mathrm{O}_{2}$ & $\mathrm{H}_{2} \mathrm{O}_{2}+\mathrm{ISD}$ & $\mathrm{H}_{2} \mathrm{O}_{2}+\mathrm{HDL}$ \\
\hline \hline $\mathrm{k}_{\text {inact }}\left(\mathrm{min}^{-1}\right)$ & $0.074 \pm 0.009$ & $0.149 \pm 0.012$ & $0.110 \pm 0.012$ \\
\hline $\mathrm{K}_{\mathrm{i}}(\mathrm{mM})$ & $0.347 \pm 0.035$ & $0.457 \pm 0.055$ & $0.393 \pm 0.018$ \\
\hline $\mathrm{k}_{\text {inact }} / \mathrm{K}_{\mathrm{i}}\left(\mathrm{min}^{-1} \mathrm{mM}^{-1}\right)$ & $0.213 \pm 0.029$ & $0.326 \pm 0.042$ & $0.280 \pm 0.052$ \\
\hline
\end{tabular}

affinity of MPO for $\mathrm{H}_{2} \mathrm{O}_{2}$ under inactivation conditions. Hence, it appears that while the hydrazides enhanced the maximum inactivation rate, they did not stimulate the binding and conversion of $\mathrm{H}_{2} \mathrm{O}_{2}$ to the reactive inactivating species by MPO at its active site. The hydrazides also stimulated the inactivation rate efficiency or 'inactivation specificity constant' $\left(\mathrm{k}_{\text {inact }} / \mathrm{K}_{\mathrm{I}}\right)$ due to $\mathrm{H}_{2} \mathrm{O}_{2}$, the value increasing from $0.213 \mathrm{~min}^{-1} \mathrm{mM}^{-1}$ to 0.326 and $0.280 \mathrm{~min}^{-1} \mathrm{mM}^{-1}$ by ISD and HDL respectively.

Table 2. Bimolecular Inactivation Rate Enhancement Factors for ISD and HDL Stimulation of $\mathrm{H}_{2} \mathrm{O}_{2}$-Dependent Inactivation of MPO. Values are Mean \pm Standard Deviation from Four Experiments

\begin{tabular}{|c|c|c|}
\hline & ISD & HDL \\
\hline \hline $\mathrm{k}_{\mathrm{enh}}\left(\mathrm{min}^{-1} \mathrm{mM}^{-1}\right)$ & $0.184 \pm 0.032$ & $0.091 \pm 0.008$ \\
\hline $\mathrm{k}^{*}{ }_{\text {enh }}\left(\mathrm{min}^{-1} \mathrm{mM}^{-1}\right)$ & $0.159 \pm 0.047$ & $0.088 \pm 0.014$ \\
\hline
\end{tabular}

\section{DISCUSSION}

Hydrazides Enhancement of $\mathrm{H}_{2} \mathrm{O}_{2}$-Dependent Inactivation of Myeloperoxidase

The results of our investigation show that presence of a donor substrate is not a requirement for the inactivation of MPO. Kinetics analysis of the $\mathrm{H}_{2} \mathrm{O}_{2}$-dependent loss of activity is consistent with an irreversible inactivation mechanism in contrast to "reversible inactivation" involving trapping of the enzyme as compound III [18]. In a series of studies on suicide inactivation of MPO by benzoic acid hydrazides [7, $9,20]$, it was suggested that a donor substrate-dependent mechanism is the main pathway for irreversible inactivation of MPO. The evidence here suggests that MPO is inactivated in a mechanism-based manner by $\mathrm{H}_{2} \mathrm{O}_{2}$, to a finite extent. The presence of the hydrazide, ISD or HDL, greatly accelerated the inactivation process. This finding is consistent with earlier studies on MPO inactivation $[8,10,20]$ where the rates and extents of inactivation were markedly stimulated by the presence of a reductant substrate capable of generating inactivating intermediates or products.

We used steady state kinetics analysis to study the enhancement of $\mathrm{H}_{2} \mathrm{O}_{2}$-mediated inactivation of MPO by hydrazide donor substrates. The concentration-dependence of $\mathrm{H}_{2} \mathrm{O}_{2}$ on MPO inactivation has the same pattern in the absence and presence of the two hydrazides studied. Such pattern indicates at least a two-step mechanism for the inactivation process: an initial binding step followed by a step involving or leading to the inactivation. The reaction of native MPO with $\mathrm{H}_{2} \mathrm{O}_{2}$ to form compound $\mathrm{I}$ and the subsequent formation of the inactivating species via other redox intermediates of the enzyme may account for this kinetics. The observation that the presence of ISD and HDL did not change the kinetics pattern of inactivation of MPO by $\mathrm{H}_{2} \mathrm{O}_{2}$ but enhanced the rate and extent of the process suggests that inactivation by $\mathrm{H}_{2} \mathrm{O}_{2}$ alone and in combination with the hydrazides might be via a common mechanism. It could be that the hydrazides enhanced the generation of the same inactivating species involved in $\mathrm{H}_{2} \mathrm{O}_{2}$-dependent loss of enzyme activity. This is consistent with the inactivation kinetics constants derived from the Kitz-Wilson plots (Fig. 3B).

While the two hydrazides increased the $\mathrm{k}_{\text {inact }}$ of the process, both decreased the affinity of the enzyme for $\mathrm{H}_{2} \mathrm{O}_{2}$ as indicated by the increase in $\mathrm{K}_{\mathrm{i}}$ values. This suggests some competitive effect of ISD and $\mathrm{HDL}$ with $\mathrm{H}_{2} \mathrm{O}_{2}$ during the inactivation of MPO. This competition may be best viewed in terms of the interaction of the reactive forms i.e. the actual inactivating species of the compounds with the susceptible intermediate of the enzyme. This is a plausible explanation since the reductants are more likely to bind after $\mathrm{H}_{2} \mathrm{O}_{2}$ has reacted with the resting enzyme to form compound I [1]. Another possible explanation is that $\mathrm{H}_{2} \mathrm{O}_{2}$ and the hydrazides could compete for reaction with either compound I or compound II. These reactions might account for the increase in $\mathrm{K}_{\mathrm{i}}$ for $\mathrm{H}_{2} \mathrm{O}_{2}$ due to the hydrazides. Goodwin et al. [11] reported that ISD enhanced the $\mathrm{H}_{2} \mathrm{O}_{2}$-dependent inactivation of horseradish peroxidase. The report suggested that inactivation rate enhancement by ISD may involve a mechanism similar to that due to $\mathrm{H}_{2} \mathrm{O}_{2}$ alone. ISD caused the accumulation of the enzyme as P670. This intermediate has been associated with the $\mathrm{H}_{2} \mathrm{O}_{2}$-dependent irreversible inactivation of horseradish peroxidase in the absence of reducing substrate [21].

The apparently low susceptibility of MPO to $\mathrm{H}_{2} \mathrm{O}_{2}$ inactivation reported here and elsewhere $[8,10,20]$ might be due to its unusual or atypical stoichiometry in its reaction with the oxidant. MPO compound I formation requires a high concentration of $\mathrm{H}_{2} \mathrm{O}_{2}$. This behaviour has been attributed to the reversibility of compound I reaction [22] and to the ability of compound I to oxidize $\mathrm{H}_{2} \mathrm{O}_{2}$ to compound II [22, 23]. This requirement for a relatively high $\mathrm{H}_{2} \mathrm{O}_{2}$ concentration may also be linked to the pseudo-catalase activity of the enzyme [24, 25]. Steady conversion of $\mathrm{H}_{2} \mathrm{O}_{2}$ to water and molecular oxygen may further protect the enzyme from inactivation under conditions in which Ferrous MPO is 
formed. Reaction of Ferrous MPO with oxygen will direct the enzyme along the turnover rather than the inactivation route [20]. The unusual covalent attachment of haem to the protein moiety of the enzyme may confer some resistance to $\mathrm{H}_{2} \mathrm{O}_{2}$-dependent inactivation.

\section{Inactivation Rate Enhancement Factors}

We have used two parameters to describe rate enhancement of MPO suicide inactivation by donor substrates: Inactivation Rate Enhancement Factor $\left(\mathrm{k}_{\text {enh }}\right)$ and the Specific Inactivation Rate Enhancement Factor $\left(\mathrm{k}^{*}{ }_{\mathrm{enh}}\right)$. The former, $\mathrm{k}_{\mathrm{enh}}$, was obtained from the slope of the plot of $\mathrm{k}_{\mathrm{obs}}$ versus ISD or HDL concentrations (Figs. 1B and 2B). While $\mathrm{k}_{\mathrm{enh}}$ gives an indication of the extent to which the hydrazides stimulate the inactivation rates due to $\mathrm{H}_{2} \mathrm{O}_{2}$, it confounds the inactivation enhancement caused by the hydrazide with inactivation due to $\mathrm{H}_{2} \mathrm{O}_{2}$ alone. We attempt to resolve the two effects by describing a new kinetics parameter, the specific inactivation rate enhancement factor $\left(\mathrm{k}^{*}{ }_{\mathrm{enh}}\right)$. This involves obtaining $\mathrm{k}_{\mathrm{hyd}}-\mathrm{k}_{\text {per }}$ by subtracting the first order inactivation rates in the absence of the respective hydrazides from those determined at different hydrazides concentrations. The plots shown in Figs. (1C and 2C) are used in estimating the specific inactivation enhancement rates, by plotting $\mathrm{k}_{\mathrm{hyd}}-\mathrm{k}_{\mathrm{per}}$ versus the concentrations of ISD and HDL respectively. From the slopes of the plots shown in Figs. (1C and 2C), $\mathrm{k}^{*}{ }_{\text {enh }}$ values were obtained. A similar approach has been used in analyzing the effects of a non-essential activator on an enzyme system in which there is finite activity in the absence of the activator [19]. Such procedure could be useful in analyzing inactivation rate enhancement by donor substrates since $\mathrm{H}_{2} \mathrm{O}_{2}$ alone caused some inactivation of the enzyme.

Other hydroperoxides that serve as oxidant for peroxidases also cause inactivation at high concentrations [1]. Hence, a kinetics parameter that defines the specific contribution of reductants to hydroperoxide-initiated inactivation of peroxidases is of significant mechanistic interest. The specific inactivation rate enhancement factor $\left(\mathrm{k}^{*}{ }_{\text {enh }}\right)$ defined in this study could be a simple parameter for describing the rate enhancing effect of a reductant such as the two hydrazides considered here. It would be interesting to see if a given inactivating donor substrate will have comparable $\mathrm{k}^{*}{ }_{\text {enh }}$ values when its effect is studied with different peroxides. We have preliminary evidence that analysis of protection of horseradish peroxidase from inactivation by efficient donor substrates using $\mathrm{k}_{\text {enh }}$ and $\mathrm{k}^{*}{ }_{\text {enh }}$ provide interesting mechanistic insight into inactivation protection mechanisms (Iniaghe et al, unpublished observation). Peroxidases have diverse industrial applications [5]. However, their inactivation by $\mathrm{H}_{2} \mathrm{O}_{2}$ even at catalytic concentrations and by the oxidation products of the donor substrates limit their practical applications. Studies on how the enzymes are inactivated are essential to understanding how to optimize their industrial uses. It is equally important to investigate and describe strategies to minimize inactivation during catalysis $[5,26]$. The new kinetics parameters defined here would be relevant in the study of mechanism-based inactivation of peroxidases and related systems [27]. The kinetics constants for the reducing substrate may provide valuable information in structure activity studies of inactivating substrates.

\section{REFERENCES}

[1] Dunford HB. Peroxidases. Adv Inorg Biochem 1982; 4: 41-68.

[2] Andrews PC, Krinsky NI. The reductive cleavage of myeloperoxidase in half, producing enzymically active hemi-myeloperoxidase. J Biol Chem 1981; 256: 4211-8.

[3] Zeng J, Fenna RE. X-ray crystal structure of canine myeloperoxidase at $3 \AA$ resolution. J Mol Biol 1992; 226: 185-207.

[4] Hurst JK. Myeloperoxidase: active site structure and catalytic mechanisms. Peroxidase. In: Everse J, Everse KE, Grisham MB, Eds. Chemistry and Biology CRC, Boca Raton 1991; pp.37-62.

[5] Valderrama B, Ayala M, Vazquez-Duhalt R. Suicide inactivation of peroxidases and the challenge of engineering more robust enzymes. Chem Biol 2002; 9: 555- 65.

[6] Vazquez-Duhalt R. Cytochrome c as a biocatalyst. J Mol Cat B Enz 1999; 7: 241-9.

[7] Kettle AJ, Gedye, CA, Hampton, MB, Winterbourn CC. Inhibition of myeloperoxidase by benzoic acid hydrazides. Biochem J 1995; 308: 559-63.

[8] Qian M, Eaton JW, Wolff SF. Cyanate-mediated inhibition of neutrophil myeloperoxidase activity. Biochem J 1997; 326: 15966.

[9] Burner U, Obinger C, Paumann M, Furtmuller PJ, Kettle AJ. Transient and steady state kinetics of the oxidation of substituted benzoic acid hydrazides by myeloperoxidase. J Biol Chem 1999; 274: 9474-592.

[10] Van Zyl JM, Bason K, Uebel RA, Van der Walt BJ. Isoniazidmediated irreversible inhibition of the myeloperoxidase antimicrobial system of the human neutrophill and the effect of thyronines. Biochem Pharmacol 1989; 38: 2363- 73.

[11] Goodwin DC, Grover TA, Aust SD. Roles of efficient substrates in enhancement of peroxidase-catalyzed oxidations. Biochemistry 1997; 36: 139-47.

[12] Ikeda-Saito M, Prince RC. The effect of chloride on the redox and EPR properties of myeloperoxidase. J Biol Chem 1985; 260: 8301-6.

[13] Odajima T, Yamaxaki I. Myeloperoxidase of the leukocyte of normal blood. III. Reduction of myeloperoxidase with hydrogen peroxide. Biochim Biophys Acta 1970; 206: 71-7.

[14] Marquez LA, Dunford HB. Mechanism of the oxidation of 3, 3', 5 , 5'-tetramethylbenzidine by myeloperoxidase determined by transient and steady-state kinetics. Biochemistry 1997; 36: 934955.

[15] Olorunniji FJ, Malomo SO, Adediran SA, Odutuga AA. Promethazine oxidation by redox mediation in peroxidase reactions. Arch Biochem Biophys 2000; 380: 251-6.

[16] Cotton ML, Dunford HB. Studies on horseradish peroxidase XI Nature of compounds I and II as determined from the kinetics of the oxidation of ferrocyanide. Can J Chem 1973; 51: 582-7.

[17] Nelson DP, Kiesow LA. Enthalpy of decomposition of hydrogen peroxide by catalase at $25^{\circ} \mathrm{C}$ (with molar extinction coefficients of $\mathrm{H}_{2} \mathrm{O}_{2}$ solutions in the UV). Anal Biochem 1972; 49: 474-8.

[18] Huwiler M, Jenzer H, Kohler H. The role of compound III in reversible and irreversible inactivation of lactoperoxidase. Eur J Biochem 1986; 158: 609-14.

[19] Cornish-Bowden A. Fundamentals of enzyme kinetics. 3rd ed. London: Portland Press 2004.

[20] Kettle AJ, Gedye CA, Winterbourn CC. Mechanism of inactivation of myeloperoxidase by 4-aminobenzoic acid hydrazide. Biochem J 1997; 321: 503-8.

[21] Adediran SA. Kinetics of the formation of p-670 and of the decay of compound III of horseradish peroxidase. Arch. Biochem. Biophys 1996; 327: 279-84.

[22] Marquez LA, Huang JT, Dunford HB. Spectral and kinetic studies on the formation of myeloperoxidase compound I and II: Roles of hydrogen peroxide and superoxide. Biochemistry 1994; 33: 144754.

[23] Bolscher BGJM, Wever R. A kinetic study of the reaction between human myeloperoxidase, hydroperoxides and cyanide inhibition 
by chloride and thiocyanate. Biochim Biophys Acta 1984; 788:110 .

[24] Iwamoto H, Kobayashi T, Hasegawa E, Morita Y. Reaction of human myeloperoxidase with hydrogen peroxide and its true catalase activity. J Biochem 1987; 101: 1407-12.

[25] Kettle AJ, Winterbourn, CC. A kinetic analysis of the catalase activity of myeloperoxidase. Biochemistry 2001; 40: 10204-12.
[26] Ryan BJ, Faragan CO. Effects of single mutations on the stability of horseradish peroxidase to hydrogen peroxide. Biochimie 2007; 89: 1029-32.

[27] Grey CE, Rundbäck F, Adlercreutz P. Improved operational stability of chloroperoxidase through use of antioxidants. J Biotechnol 2008; 135:196-201.

(C) Olorunniji et al.; Licensee Bentham Open.

This is an open access article licensed under the terms of the Creative Commons Attribution Non-Commercial License (http://creativecommons.org/licenses/by-nc/3.0/) which permits unrestricted, non-commercial use, distribution and reproduction in any medium, provided the work is properly cited. 